\title{
Clinical Pharmacology of Gentamicin in the Newborn Infant
}

\author{
R. D. G. MILNER, JULIA ROSS, D. J. R. FROUD, and J. A. DAVIS \\ From the Department of Child Health, University of Manchester
}

\begin{abstract}
Milner, R. D. G., Ross, J., Froud, D. J. R., and Davis, J. A. (1972). Archives of Disease in Childhood, 47, 927. Clinical pharmacology of gentamicin in the newborn infant. Newborn infants with suspected bacterial infection were treated with intramuscular gentamicin. Serum levels of the drug were measured 1 hour after the first dose, immediately before the second dose, and immediately before and 1 hour after a dose given on the third day.

On a low dosage regimen ( $1 \mathrm{mg} / \mathrm{kg}$ every 8 hours) 9 of 17 infants had serum gentamicin levels below the required minimum level of $1 \mu \mathrm{g} / \mathrm{ml}$ immediately before the second dose, and 5 of 19 infants had similarly low levels on the third day. On a high dosage regimen ( $3 \mathrm{mg} / \mathrm{kg}$ initially, then $2 \mathrm{mg} / \mathrm{kg}$ every 8 hours) 2 of 10 infants had preinjection serum gentamicin levels below $1 \mu \mathrm{g} / \mathrm{ml}$ on the first day, and 3 out of 16 had similar levels on the third day. The mean $( \pm S E)$ serum gentamicin level on the high dosage regimen was $5 \cdot 0 \pm 0.5 \mu \mathrm{g} / \mathrm{ml} 1$ hour after the first injection, $1 \cdot 9 \pm 0 \cdot 4$ $\mu \mathrm{g} / \mathrm{ml}$ just before the second injection, and on the third day $1.9 \pm 0.3 \mu \mathrm{g} / \mathrm{ml}$ just before an injection and 5.1 $\pm 0.5 \mu \mathrm{g} / \mathrm{ml} 1$ hour after injection. The highest serum gentamicin level recorded in any of the 40 infants studied was $8.2 \mu \mathrm{g} / \mathrm{ml}$.

On the first day of treatment with the low dose regimen, a mean of $21 \%$ (range 9$68 \%$ ) of the injected dose was recovered from the urine; and on the third or fourth day a mean of $44 \%$ (range $17-76 \%$ ) of the gentamicin injected on that day was recovered.

In 4 infants who died tissue gentamicin levels were measured in the liver, lungs, heart, kidneys, and brain, the highest concentration being in the kidney with low levels in the heart, liver, and brain, while levels in the lungs were intermediate. Neonatal renal and pulmonary infections are thus likely to be suitably treated with gentamicin.

Bacteriological studies confirmed the effectiveness of gentamicin in the treatment of neonatal infection, but a dosage regimen derived by extrapolation from older children frequently resulted in inadequate serum levels, and a higher dosage regimen giving more satisfactory results was therefore defined.
\end{abstract}

The effectiveness of gentamicin in vitro against Pseudomonas pyocyanea and other bacterial species commonly found in hospital nurseries (Barber and Waterworth, 1966) makes this a potentially useful antibiotic in the treatment of neonatal infection but there has been a lack of information about the appropriate dosage regimen for this age group. Studies on the clinical pharmacology in the neonatal period of antibiotics related to gentamicin (Axline and Simon, 1964) have clearly shown the inadequacy of deriving a neonatal dose regimen from

Received 2 May 1972. extrapolation of adult dosage on a bodyweight or surface area basis. Gentamicin, like the aminoglycosides, is excreted largely by glomerular filtration (Black et al., 1963), and serum levels are therefore much influenced by renal function as well as by dose size, route of administration, and rate of absorption. These variables make it important to estimate directly the effective dosage regimen in the neonatal period. The few studies so far published (Ito, 1970; McCracken and Jones, 1970) have reported very different serum levels from similar dosage regimens.

The purpose of the present study was to deter- 
mine the serum levels of gentamicin achieved on a dosage regimen which was thought unlikely to cause renal damage or ototoxicity. The serum level measured 1 hour after the first injection was taken as an index of the peak antibiotic activity (McCracken and Jones, 1970), and the level immediately before the second injection as a reflection of the minimum circulating level. The measurements were repeated on the third day to see if accumulation of the drug had occurred. Urinary excretion of gentamicin was measured in male infants. In 4 babies who died the opportunity was taken to measure the concentration of gentamicin in various tissues. When an appreciable number of infants was found to have inadequate serum levels on the low dosage regimen, a second group was studied which received higher doses. The results of the work made it possible to define a dosage regimen which gave therapeutic serum levels of the drug without achieving concentrations likely to have toxic effects.

\section{Patients and Methods}

Clinical. The patients studied were infants admitted to the Special Care Baby Unit who were considered to need systemic antibiotic treatment. Before the period of study the systemic antibiotic combination used routinely was penicillin $G$ and kanamycin. This was changed to gentamicin which was given by intramuscular injection $1 \mathrm{mg} / \mathrm{kg}$ body weight every 8 hours for 15 doses. Later in the study the dose was changed to $3 \mathrm{mg} / \mathrm{kg}$ body weight for the first dose followed by $2 \mathrm{mg} / \mathrm{kg}$ every 8 hours for 14 doses. These are referred to as low and high dose regimens, respectively. The preparation injected was gentamicin sulphate, but all doses were calculated in terms of gentamicin base. The decision to give antibiotics rested on a clinical diagnosis of probable systemic bacterial infection. Before starting gentamicin therapy blood was collected for culture, full blood count, and serum immunoglobulin determinations. Bacterial swabs were taken from the nose, throat, umbilicus, and rectum. When indicated, urine and CSF were also collected for bacterial culture.

Forty patients were studied varying in gestational age from 27 to 42 weeks (Fig. 1) and in birthweight from 900 to $3840 \mathrm{~g}$. In the smallest infant born at 27 weeks with a birthweight of $900 \mathrm{~g}$, all gentamicin injections were given intraperitoneally. Therapy began at an age of 1 to 36 days. One hour after the first dose $1 \mathrm{ml}$ blood was collected by heel prick in a plastic tube. Serum was separated and stored at $-20^{\circ} \mathrm{C}$. Another blood sample was collected immediately before the second dose of gentamicin. Samples were collected on the third day of treatment immediately before and 1 hour after a dose of gentamicin. An attempt was made to collect 24-hour urine samples on the first and third or fourth day of treatment from all male infants. Urine samples were collected as soon as possible after micturi- tion and stored at $4{ }^{\circ} \mathrm{C}$ until the 24-hour collection was complete. The samples were mixed well and an aliquot was stored at $-20^{\circ} \mathrm{C}$ for measurement of urinary gentamicin concentration. In some cases gentamicin concentrations were measured in every sample of urine so that the pattern of gentamicin excretion during the collection period could be recorded. Not all samples were collected in every case.

Four infants died. At necropsy, which was performed within 24 hours of death, a piece of brain, heart, lung, liver, and kidney was collected and stored at $-20^{\circ} \mathrm{C}$.

The concentration of gentamicin in a biological fluid or tissue was measured in quadruplicate by a diffusion inhibition method in an agar plate seeded with Bacillus pumilis (Froud and Froud, 1972). The assay measured microbiologically active gentamicin only. A series of standard solutions of gentamicin

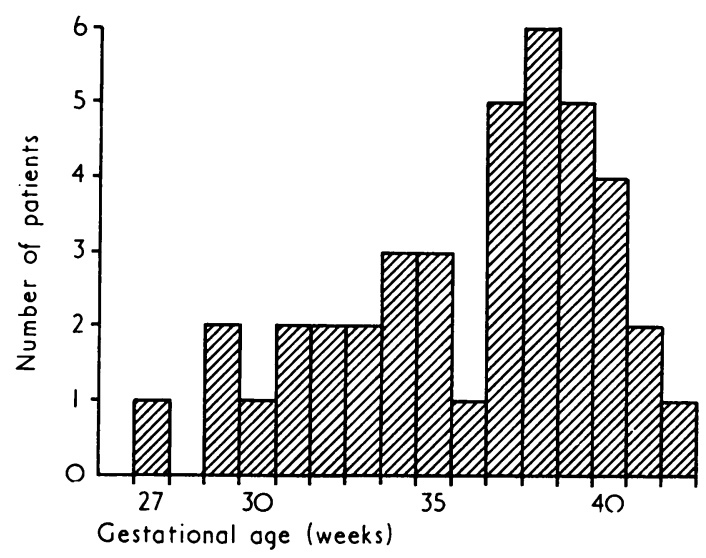

FIG. 1.-Histogram of number of patients studied by gestational age.

sulphate ranging from 0.625 to $20 \mu \mathrm{g} / \mathrm{ml}$ gentamicin base was included in each assay. After inactivation by heating to $56^{\circ} \mathrm{C}$ for 30 minutes, each serum sample was tested neat and at dilutions of $1: 2,1: 4$, and $1: 8$ in $0 \cdot 1$ moles/l. phosphate buffer of $p \mathrm{H} 8 \cdot 0$. Preliminary assays of gentamicin concentration were made in urine diluted $1: 10$ and $1: 100$ in phosphate buffer. When an idea of the urinary gentamicin level was recorded, four appropriate geometric dilutions of the urine sample were made so that each dilution fell within the range covered by the standard curve. $10 \mathrm{~g}$ phosphate buffer solution was added to each sample of tissue in its container. The tissue was disrupted ultrasonically to produce a homogeneous suspension in the buffer. After decanting the suspension the container was reweighed to estimate the weight of the tissue sample. The suspension was treated in the same way as serum samples and the results were expressed in $\mu \mathrm{g}$ gentamicin $/ \mathrm{g}$ tissue. 


\section{Results}

Clinical. The commonest indication for starting gentamicin therapy was the likelihood of pneumonia (20 patients) associated with pulmonary oedema or due to aspiration or repeated intubation. Other indications were: suspected septicaemia (9), suspected or proven maternal bacterial infection (4), suspected meningitis (3), inflammation around the umbilicus (3), and parotid abscess (1). In 21 infants one or more potentially pathogenic organisms were cultured and in 19 no pathogens were grown. The pathogenic bacteria were those commonly found in the newborn: Esch. coli, Staphylococcus aureus, Klebsiella spp., Pseudomonas spp, and Proteus spp. Every strain isolated, with one exception, was shown to be sensitive to gentamicin in vitro. The exception was the infant with a parotid abscess from which Staph. aureus and a Klebsiella sp were cultured. The klebsiella was sensitive to gentamicin in vitro but the sensitivity of the staphylococcus to gentamicin was not tested. Since the infant did not improve clinically in 3 days, antibiotic treatment was changed to penicillin and kanamycin after which recovery occurred. In 6 cases Esch. coli sensitive to gentamicin in vitro was cultured from the nose or throat swab of an infant who was clinically well and who had completed a course of gentamicin therapy.

Of the 4 infants who died, 2 (Cases 11 and 24) had no demonstrable bacterial infection at necropsy but had been given gentamicin because of suspected pneumonia: the causes of death were an intracranial haemorrhage and a massive pulmonary haemorrhage, respectively. The other 2 died from secondary bacterial infection shortly after completing a course of treatment with gentamicin which had cured a primary bacterial infection. Case 3, a second twin born at 32 weeks weighing $1540 \mathrm{~g}$ had a persistent ductus arteriosus, heart failure, and pneumonia on the second day of life. Treatment with gentamicin $(1 \mathrm{mg} / \mathrm{kg})$ was started and a Klebsiella sp was cultured from nose and throat swabs. After initial improvement the baby deteriorated and died 4 days later due to an Esch. coli meningitis. The Esch. coli cultured from the CSF was sensitive to gentamicin in vitro. The other infant who died (Case 25) was born at 27 weeks weighing $900 \mathrm{~g}$. He was treated with gentamicin $(1 \mathrm{mg} / \mathrm{kg}$ intraperitoneally) from the 8th to the 13th day because Pseudomonas aeruginosa sensitive to gentamicin was cultured from the throat and heel. 2 days after completion of gentamicin therapy he died from an overwhelming infection with Esch. coli type 6.

Serum gentamicin levels. 23 infants were treated with gentamicin in low dosage. The mean $( \pm S E)$ serum level 1 hour after the first dose was $1 \cdot 8 \pm 0.3 \mu \mathrm{g} / \mathrm{ml}$, and immediately before the second dose $1 \cdot 0 \pm 0 \cdot 2 \mu \mathrm{g} / \mathrm{ml}$ (Table I). On the third day of treatment the mean serum level before a gentamicin injection was $1.9 \pm 0.3 \mu \mathrm{g} / \mathrm{ml}$ and 1 hour after an injection, $3 \cdot 3 \pm 0 \cdot 4 \mu \mathrm{g} / \mathrm{ml}$. On the first day, 4 of 19 infants had serum gentamicin levels below $1 \mu \mathrm{g} / \mathrm{ml} 1$ hour after the first dose, and 9 of 17 infants had serum gentamicin levels below $1 \mu \mathrm{g} / \mathrm{ml}$ just before the second dose. Serum levels below $1 \mu \mathrm{g} / \mathrm{ml}$ on the third day of treatment occurred in 1 of 21 infants 1 hour after an injection, and in 5 of 19 infants just before an injection.

Seventeen infants were treated with the high dose regimen. The mean $( \pm S E)$ serum level 1 hour after the first dose was $5 \cdot 0 \pm 0.5 \mu \mathrm{g} / \mathrm{ml}$ and just before the second dose, $1 \cdot 9 \pm 0 \cdot 4 \mu \mathrm{g} / \mathrm{ml}$. On the third day the mean serum level just before an injection was $1.9 \pm 0.3 \mu \mathrm{g} / \mathrm{ml}$ and 1 hour after an injection was $5 \cdot 1 \pm 0.5 \mathrm{\mu g} / \mathrm{ml}$. Serum levels of gentamicin below $1 \mu \mathrm{g} / \mathrm{ml} 1$ hour after an injection were not observed on the first or third day of treatment. Immediately before an injection 2 of 10 infants had a serum gentamicin level below

TABLE I

Serum Gentamicin Concentrations in Newborn Infants

\begin{tabular}{|c|c|c|c|c|}
\hline \multirow{3}{*}{ Dosage Regimen } & \multicolumn{4}{|c|}{$\begin{array}{l}\text { Mean } \pm \text { SE Serum Gentamicin Concentration }(\mu \mathrm{g} / \mathrm{ml}) \\
\text { (No. of observations in parentheses) }\end{array}$} \\
\hline & \multicolumn{2}{|c|}{ Day 1} & \multicolumn{2}{|c|}{ Day 3} \\
\hline & $\begin{array}{l}1 \mathrm{Hr} \text { After } \\
\text { First Injection }\end{array}$ & $\begin{array}{l}\text { Immediately Before } \\
\text { Second Injection }\end{array}$ & $\begin{array}{l}1 \mathrm{Hr} \text { After } \\
\text { Injection }\end{array}$ & $\begin{array}{l}\text { Immediately } \\
\text { Before Injection }\end{array}$ \\
\hline $\begin{array}{l}1 \mathrm{mg} / \mathrm{kg} \text { i.m. } 8 \text { hourly } \times 15 \text { doses } \\
3 \mathrm{mg} / \mathrm{kg} \text { first dose, then } 2 \mathrm{mg} / \mathrm{kg} 8 \text { hourly } \times 14 \text { doses }\end{array}$ & $\begin{array}{l}1 \cdot 8 \pm 0 \cdot 3(19) \\
5 \cdot 0 \pm 0 \cdot 5(13) \star\end{array}$ & $\begin{array}{l}1 \cdot 0 \pm 0 \cdot 2(17) \\
1 \cdot 9 \pm 0 \cdot 4(10) \dagger\end{array}$ & $\begin{array}{l}3 \cdot 3 \pm 0 \cdot 4(21) \\
5 \cdot 1 \pm 0 \cdot 5(15) \ddagger\end{array}$ & $\begin{array}{l}1 \cdot 9 \pm 0 \cdot 3(19) \\
1 \cdot 9 \pm 0 \cdot 5(16)\end{array}$ \\
\hline
\end{tabular}

Mean serum level on high dose regimen significantly greater than on low dose regimen, $\star P<0.001,+P<0.05, \ddagger P<0.01$. 
$1 \mu \mathrm{g} / \mathrm{ml}$ on the first day, and on the third day 3 of 16 infants had a serum level of less than $1 \mu \mathrm{g} / \mathrm{ml}$ just before an injection.

Urinary gentamicin excretion. Satisfactory 24-hour urine collections were made on one or more occasions on 11 male infants who were treated with the low dose regimen. The urinary excretion of gentamicin on the first day varied between 9 and $68 \%$ and on the third or fourth day between 17 and $76 \%$ of the dose injected on that day (Table II). Examples of the pattern of gentamicin excretion are shown in Fig. 2. On the first and third days of treatment gentamicin excretion tended to rise after an injection, though the absolute amounts excreted were greater on the third than on the first day. The urinary concentration of gentamicin varied widely between infants but never exceeded 87 $\mu \mathrm{g} / \mathrm{ml}$.

Tissue gentamicin concentration. The tissue concentrations and contents of gentamicin in the kidneys, lung, liver, heart, and brain of the 4 infants who died are shown in Table III. The relative concentrations of the drug in the 5 organs were similar in each infant though the absolute concentration in an infant depended on the total number of doses of gentamicin received and the interval between the last dose and death. In each case the highest concentration of gentamicin was in the kidney and the concentration in the lung was intermediate between that found in the kidney and the low and similar levels found in the liver, heart, and brain.
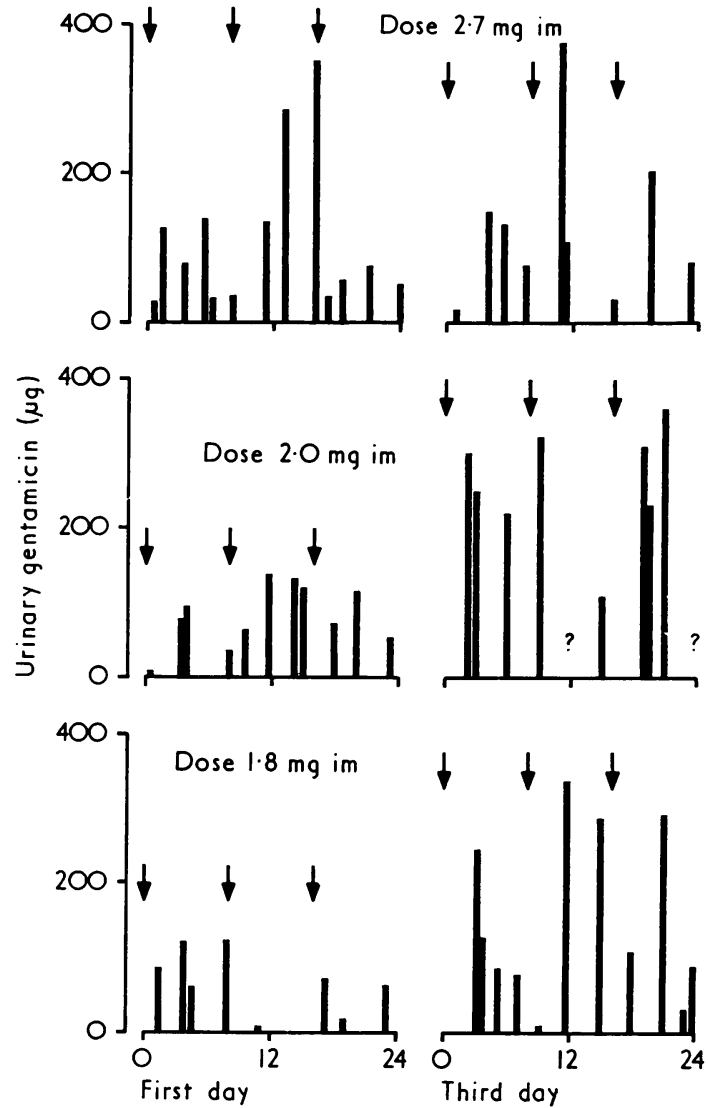

FIG. 2.-Urinary excretion of gentamicin on first and third days of treatment of 3 infants given $1 \mathrm{mg} / \mathrm{kg}$ gentamicin every $8 \mathrm{hr}$.

TABLE II

Urinary Excretion of Gentamicin in Newborn Infants

\begin{tabular}{|c|c|c|c|c|c|}
\hline \multirow{3}{*}{ Case No. } & \multirow{3}{*}{$\begin{array}{c}\text { Dose of } \\
\text { Gentamicin } \\
(\mathrm{mg} / 24 \mathrm{hr})\end{array}$} & \multicolumn{4}{|c|}{ Gentamicin Excretion (mg/24 hr) or as Percentage of Dose Injected } \\
\hline & & \multicolumn{2}{|c|}{ Day 1} & \multicolumn{2}{|c|}{ Day 3 or 4} \\
\hline & & Absolute & Percentage & Absolute & Percentage \\
\hline $\begin{array}{l}1 \\
2 \\
4 \\
5 \\
9 \\
\\
10 \\
13 \\
15 \\
17 \\
18 \\
19\end{array}$ & $\begin{array}{r}10 \cdot 5 \\
9 \cdot 0 \\
9 \cdot 0 \\
10 \cdot 5 \\
8 \cdot 4 \\
7 \cdot 2 \\
6 \cdot 0 \\
5 \cdot 4 \\
5 \cdot 4 \\
8 \cdot 1 \\
11 \cdot 4\end{array}$ & $\begin{array}{l}0 \cdot 91 \\
1 \cdot 90 \\
0 \cdot 72 \\
1 \cdot 40 \\
- \\
4 \cdot 90 \\
1 \cdot 61 \\
0 \cdot 92 \\
0 \cdot 63 \\
1 \cdot 52 \\
1 \cdot 78\end{array}$ & $\begin{array}{r}9 \\
21 \\
10 \\
13 \\
- \\
\\
68 \\
27 \\
18 \\
12 \\
19 \\
16\end{array}$ & $\begin{array}{l}\text { - } \\
- \\
\bar{Z} \cdot 20(\text { dy } 3) \\
6 \cdot 40 \text { (dy } 4) \\
4 \cdot 20 \\
1 \cdot 68 \\
2 \cdot 19 \\
1 \cdot 82 \\
1 \cdot 36 \\
6 \cdot 09\end{array}$ & $\begin{array}{l}- \\
- \\
\bar{Z} \\
38 \\
76 \\
58 \\
38 \\
41 \\
34 \\
17 \\
53\end{array}$ \\
\hline \multicolumn{2}{|c|}{$\begin{array}{c}\text { Mean } \pm \text { SE } \\
\text { (without Case 10) }\end{array}$} & & $\begin{array}{l}21 \pm 5 \\
16 \pm 2\end{array}$ & & $44 \pm 6$ \\
\hline
\end{tabular}


TABLE III

Gentamicin Content of Various Organs of Newborn Infants

\begin{tabular}{|c|c|c|c|c|c|c|c|c|c|}
\hline \multirow{2}{*}{ Case No. } & \multirow{2}{*}{$\begin{array}{l}\text { Birth- } \\
\text { weight } \\
\text { (g) }\end{array}$} & \multirow{2}{*}{$\begin{array}{c}\text { Total } \\
\text { Amount } \\
\text { Gentamicin } \\
\text { Received } \\
\text { (mg) }\end{array}$} & \multirow{2}{*}{$\begin{array}{c}\text { Interval } \\
\text { Between } \\
\text { Last Dose } \\
\text { Gentamicin } \\
\text { and Death }\end{array}$} & \multicolumn{6}{|c|}{ Concentration $(\mu \mathrm{g} / \mathrm{g})$ and Total Content Gentamicin $(\mu \mathrm{g})$ in } \\
\hline & & & & & Kidney & Lung & Liver & Heart & Brain \\
\hline $\begin{array}{r}25 \\
3 \\
24 \\
11\end{array}$ & $\begin{array}{r}900 \\
1540 \\
1760 \\
2490\end{array}$ & $\begin{array}{r}15 \cdot 0 \\
22 \cdot 5 \\
1 \cdot 5 \\
3 \cdot 0\end{array}$ & $\begin{array}{l}2 \mathrm{dy} \\
1 \mathrm{dy} \\
3 \mathrm{hr} \\
4 \mathrm{hr}\end{array}$ & $\begin{array}{l}\text { Concentration } \\
\text { Content } \\
\text { Concentration } \\
\text { Content } \\
\text { Concentration } \\
\text { Content } \\
\text { Concentration } \\
\text { Content }\end{array}$ & $\begin{array}{c}21 \cdot 8 \\
458 \\
6 \cdot 0 \\
114 \\
0 \cdot 5 \\
8 \cdot 2 \\
7 \cdot 2 \\
21 \cdot 0\end{array}$ & $\begin{array}{c}4 \cdot 1 \\
123 \\
3 \cdot 0 \\
132 \\
0 \cdot 3 \\
14 \cdot 1 \\
1 \cdot 0 \\
62\end{array}$ & $\begin{array}{r}0 \cdot 8 \\
38 \cdot 4 \\
2 \cdot 0 \\
128 \\
0 \cdot 1 \\
6 \cdot 2 \\
<0 \cdot 1 \\
9 \cdot 0\end{array}$ & $\begin{array}{l}0 \cdot 2 \\
1 \cdot 9 \\
2 \cdot 5 \\
25 \\
<0 \cdot 1 \\
<2 \cdot 0 \\
<0 \cdot 1 \\
<1 \cdot 4\end{array}$ & $\begin{array}{r}0 \cdot 2 \\
31 \cdot 6 \\
- \\
\overline{0} \\
= \\
=\end{array}$ \\
\hline
\end{tabular}

\section{Discussion}

This study was based on the premise that gentamicin was an antibiotic with a spectrum of activity appropriate to the treatment of neonatal bacterial infection and was designed to discover what dosage regimen would produce satisfactory serum drug levels. This information was necessary because if too little gentamicin was given there was the danger of low serum levels, the emergence of resistant strains of organisms, and a false impression that the drug was clinically ineffective. On the other hand, if too much was given, ototoxicity and renal damage could be anticipated.

The initial dosage regimen $(1 \mathrm{mg} / \mathrm{kg}$ body weight every 8 hours for 15 doses) was derived from the results of published studies in infants and children. Nunnery and Riley (1969) observed a mean peak serum gentamicin level of $1.88 \mu \mathrm{g} / \mathrm{ml}$ on the third day of treatment 30 minutes after the injection of $0.4 \mathrm{mg} / \mathrm{kg}$ gentamicin every 8 hours. On the basis of in vitro sensitivity tests this dosage regimen would be expected to be frequently ineffective. Klein (1969) observed a serum gentamicin level of 15.5 and $16.5 \mu \mathrm{g} / \mathrm{ml} 1$ and 2 hours after giving $5.3 \mu \mathrm{g}$ gentamicin $/ \mathrm{kg}$ to a 6 -day-old anencephalic infant.

Clinical experience with adult patients (Arcieri et al., 1970) and experimental studies (Black et al., 1963) showed that the toxic effects of gentamicin, like those of the related antibiotics, neomycin and kanamycin, were principally on the ear and kidney. In adults ototoxicity was commoner than renal damage and loss of vestibular function occurred more commonly than deafness. Many patients suffering toxic effects had impaired renal function before starting gentamicin therapy, and from the data available in man it seemed unlikely that toxic effects would occur at peak serum levels of 10 $\mu \mathrm{g} / \mathrm{ml}$ or less (Arcieri et al., 1970). The initial dosage regimen in the present study was chosen to err more towards inadequate serum levels than toxic ones.

A serum gentamicin level of less than $1 \mu \mathrm{g} / \mathrm{ml}$ was arbitrarily defined as inadequate on the basis of in vitro sensitivity tests (Barber and Waterworth, 1966; Nunnery and Riley, 1969; McCracken and Jones, 1970). The realization that nearly $20 \%$ of the infants had inadequate serum gentamicin levels 1 hour after the first dose and half had levels less than $1 \mu \mathrm{g} / \mathrm{ml}$ just before the second dose, led to reappraisal of the initial dose. Accumulation of the drug occurred and on the third day only 1 infant had an inadequate serum level 1 hour after an injection, but $25 \%$ had low levels just before an injection. The highest serum level in any of the 23 infants studied on this regimen was $7 \cdot 7 \mu \mathrm{g} / \mathrm{ml}$ and it seemed justifiable to continue the study using $2 \mathrm{mg}$ gentamicin as the repeated dose. On the high dose regimen no serum gentamicin level exceeded $8.2 \mu \mathrm{g} / \mathrm{ml}$ and all measurements of serum levels 1 hour after injection were more than $1 \mu \mathrm{g} / \mathrm{ml}$. Thus, on a limited series, the high dose regimen produced serum gentamicin levels which were effective but not expected to be toxic. The serum levels achieved in the present study were in good agreement with those reported by McCracken and Jones (1970) but were lower than those reported by Ito (1970).

The recovery of $68 \%$ of the injected dose of gentamicin in the urine of Case 10 on the first day of treatment was exceptional, the range in the other infants being from 9 to $27 \%$. No explanation having been found, the mean urinary excretion of gentamicin on the first day of treatment has been presented with and without Case 10. The pattern of excretion within a 24-hour period varied as shown by Fig. 2. Similar concentrations of the drug occurred in the urine on the first and third 
day and the increased excretion on the third day seemed to be due mainly to the larger volume of urine passed. This observation may offer a clue to the different serum levels observed by other workers in newborn infants who received similar intramuscular dosage regimens. Lower serum levels of gentamicin may occur when an infant is fed early and has thereby a larger urine output in the first days of life. The high concentration of the drug in the urine and kidney tissue suggests that it may be especially effective in the treatment of genitourinary infection if steps are taken to keep the urine alkaline. In infants with suspected impairment of renal function gentamicin should be given only if serum levels can be monitored.

The measurement of tissue gentamicin concentrations in 4 infants permits only qualitative deductions. In each case the concentrations in different organs were ranked similarly. The highest concentration occurred in the kidney as was expected from what was known of the excretion of gentamicin. The finding that levels in the lung were higher than those in the liver, heart, or brain was unexpected but reassuring, inasmuch as the clinical indication for starting treatment had been suspected pneumonia in half the cases. Gentamicin in the lung at death was probably mainly in pulmonary tissue and not blood since 2 of the infants died 24 hours or more after the last injection of gentamicin, when the drug had been eliminated from the bloodstream.

It is apparent from the accumulation of the drug by renal and pulmonary tissue that the volume of distribution of gentamicin in the newborn infant is greater than the extracellular space. This probably accounts, at least in part, for the observation that a dosage regimen which had been shown to be satisfactory for older children gave inadequate blood levels in the newborn. The high plasma concentrations of gentamicin observed by Ito (1970) in infants given $0.8-2.0 \mathrm{mg} / \mathrm{kg}$ gentamicin per 24 hours are difficult to understand for they could occur only if the volume of distribution of the drug were appreciably less than the extracellular space.

It is noteworthy that in all but one case in which pathogenic organisms were cultured the bacteria were sensitive to gentamicin in vitro. Gentamicin is relatively ineffective when given alone against Staphylococcus spp in vivo and against Streptococcus spp in vivo or in vitro (Barber and Waterworth, 1966). This was illustrated by the infant with a parotid abscess from which Staph. aureus was cultured. It would seem advisable, when using gentamicin in the treatment of unknown bacterial infection in the newborn, to combine it with another antibiotic such as penicillin G. The death of two infants from systemic Esch. coli infection after completing a course of intramuscular gentamicin treatment indicates another potential hazard. It is suggested that in these cases the secondary infection was opportunistic, occurring in a relatively bacteria-free baby.

Formal toxicity tests were not performed in the present study. Ito (1970) failed to find biochemical evidence of hepatic or renal damage in infants whose mean peak serum gentamicin levels were $9 \mu \mathrm{g} / \mathrm{ml}$. Audiometry tests are being performed on the infants who were studied here, and will be reported later.

We are grateful to the Research Grants Committee of the United Manchester Hospitals for financial support and to Roussel Laboratories Ltd. for carrying out the gentamicin assays.

\section{REFERENCES}

Arcieri, G. M., Falco, F. G., Smith, H. M., and Hobson, L. B. (1970). Clinical research experience with gentamicin, incidence of adverse reactions. Medical fournal of Australia, 1, Special Suppl. on the changing nature of bacterial infections, 13 June, 30.

Axline, S. G., and Simon, H. J. (1964). Clinical pharmacology of antimicrobial agents in premature infants. I. Kanamycin, streptomycin and neomycin. In Antimicrobial Agents and Chemotherapy, p. 135. American Society for Microbiology, Ann Arbor, Michigan.

Barber, M., and Waterworth, P. M. (1966). Activity of gentamcin against pseudomonas and hospital staphylococci. British Medical fournal, 1, 203.

Black, J., Caleswick, B., Williams, D., and Weinstein, M. J. (1963). Pharmacology of gentamicin, a new broad-spectrum antibiotic. Antimicrobial Agents and Chemotherapy, 3, 138.

Froud, D. J. R., and Froud, P. A. (1972). A simple method for the estimation of gentamicin in body fluids. Fournal of Science and Technologv, 16, 20.

Ito, T. (1970). Absorption, excretion and effects of gentamicin in new-born infants. Fapanese fournal of Antibiotics, 23, 298.

Klein, J. O. (1969). Consideration of gentamicin for therapy of neonatal sepsis. Fournal of Infectious Diseases, 119, 457.

McCracken, G. H., and Jones, L. G. (1970). Gentamicin in the neonatal period. American fournal of Diseases of Children, 120, 524.

Nunnery, A. W., and Riley, H. D., Jr. (1969). Gentamicin: pharmacologic observations in newborns and infants. Fournal of Infectious Diseases, 119, 402.

Correspondence to Dr. R. D. G. Milner, St. Mary's Hospital, Manchester M13 0JH.

\section{Note on Proof}

J. D. Nelson and G. H. McCracken, Jr., American Journal of Diseases of Children (1972) 124, 13, have recently summarized their experience with gentamicin in the treatment of neonatal infection and conclude that a dosage regimen similar to the high regimen described here is the one of choice. They recommend that infants aged up to 7 days be given $2.5 \mathrm{mg}$ gentamicin $/ \mathrm{kg}$ every $12 \mathrm{hr}$ and older infants the same dose every $8 \mathrm{hr}$. 